\title{
Aortic valve endocarditis due to Bartonella clarridgeiae in a dog in Brazil
}

\author{
Endocardite de válvula aórtica por Bartonella clarridgeiae em um cão no Brasil \\ Marcos Rogério André1* (D); Raphaela Arantes Marques Canola²; Jaislane Bastos Braz²; Isabella Fernanda Spinelli Perossi³; \\ Ana Claudia Calchi ${ }^{1}$; Priscila Ikeda ${ }^{1}$; Rosangela Zacarias Machado ${ }^{1}$; Rosemeri de Oliveira Vasconcelos ${ }^{3}$; \\ Aparecido Antonio Camacho ${ }^{2}$

\begin{abstract}
${ }^{1}$ Laboratório de Imunoparasitologia, Departamento de Patologia Veterinária, Faculdade de Ciências Agrárias e Veterinárias - FCAV, Universidade Estadual Paulista "Júlio de Mesquita Filho" - UNESP, Jaboticabal, SP, Brasil

${ }^{2}$ Serviço de Cardiologia Veterinária, Hospital Veterinário e Departamento de Clínica e Cirurgia Veterinária, Faculdade de Ciências Agrárias e Veterinárias - FCAV, Universidade Estadual Paulista "Júlio de Mesquita Filho" - UNESP, Jaboticabal, SP, Brasil

${ }^{3}$ Serviço de Patologia Veterinária, Departamento de Patologia Veterinária, Faculdade de Ciências Agrárias e Veterinárias - FCAV, Universidade Estadual Paulista "Júlio de Mesquita Filho" - UNESP, Jaboticabal, SP, Brasil
\end{abstract}

Received June 24, 2019

Accepted September 6, 2019

\begin{abstract}
We report the first documented case of endocarditis associated with Bartonella clarridgeiae in a dog in Latin America. Infective vegetative valvular aortic endocarditis was diagnosed in a 10 -year-old male mixed breed dog. The dog presented grade V/VI systolic and diastolic murmur, hyperthermia, and progressive weight loss. Cardiomegaly and presence of diffuse alveolar pattern in the lung fields were observed in the thorax radiography evaluation. Irregular and hyperechogenic structures adhered to the aortic leaflets, causing obstruction of the left ventricular outflow tract and severe aortic insufficiency, were observed in the echocardiography evaluation. A vegetative, whitish, hardened structure measuring $1.0 \mathrm{~cm}$ in diameter was observed in aortic semilunar valve at necropsy. Based on a combination of pre-enrichment insect-based medium liquid culture, quantitative real-time and conventional PCR assays based on nuo $G$ and $g l t A$ genes, respectively, followed by sequencing and phylogenetic inferences, B. clarridgeiae DNA was detected in the patient's aortic valve lesions. Clinical, echocardiographic, anatomopathologic and molecular features supported the diagnosis of severe aortic vegetative endocarditis possibly caused by B. clarridgeiae in a dog in Brazil.
\end{abstract}

Keywords: Bartonella clarridgeiae, endocarditis, dog, Brazil.

\section{Resumo}

Relatamos o primeiro caso documentado de endocardite associada à Bartonella clarridgeiae em um cão na América Latina. Endocardite aórtica valvar vegetativa infecciosa foi diagnosticada em um cão sem raça definida de 10 anos de idade. O cão apresentou sopro sistólico e diastólico de grau V / VI, hipertermia e perda progressiva de peso. Cardiomegalia e presença de padrão alveolar difuso nos campos pulmonares foram observados na avaliação radiográfica do tórax. Estruturas irregulares e hiperecogênicas aderidas aos folhetos aórticos, causando obstrução da via de saída do ventrículo esquerdo e insuficiência aórtica grave, foram observadas na avaliação ecocardiográfica. À necropsia, foi observada uma estrutura vegetativa, esbranquiçada e endurecida medindo $1,0 \mathrm{~cm}$ de diâmetro na válvula semilunar aórtica. Por meio de uma combinação de cultura líquida baseada em meio de pré-enriquecimento de inseto, ensaios de PCR quantitativa em tempo real e convencional baseados nos genes nuo $G$ e $g l t A$, respectivamente, seguidos de sequenciamento e inferências filogenéticas, DNA de $B$. clarridgeiae foi detectado no tecido valvular lesionado do paciente. O diagnóstico de endocardite vegetativa aórtica grave, possivelmente causado por $B$. clarridgeiae em um cáo no Brasil, foi apoiado por características clínicas, ecocardiográficas, anatomopatológicas e moleculares.

Palavras-chave: Bartonella clarridgeiae, endocardite, cão, Brasil.

\footnotetext{
*Corresponding author: Marcos Rogério André. Laboratório de Imunoparasitologia, Departamento de Patologia Veterinária, Faculdade de Ciências Agrárias e Veterinárias - FCAV, Universidade Estadual Paulista "Júlio de Mesquita Filho" - UNESP, Campus de Jaboticabal, Via de Acesso Prof. Paulo Donato Castellane, s/n, Zona Rural, CEP 14884-900, Jaboticabal, SP, Brasil. e-mail: mr.andre@unesp.br
} 


\section{Introduction}

Although infrequently diagnosed, infectious endocarditis (IE) has been associated with high morbidity and mortality in dogs (FENIMORE et al., 2011). IE has been associated with congestive heart failure, fever, heart murmurs, arrythmias, thromboembolism, immune-mediated glomerulonephritis and polyarthritis (MACDONALD et al., 2004). Among the pathogens associated with IE in dogs, Bartonella-associated endocarditis stands out because of its high occurrence in dogs (32 cases registered in the literature before this present communication) (BREITSCHWERDT et al., 1995, 1999; CHOMEL et al., 2001, 2003, 2009; MACDONALD et al., 2004; KELLY et al., 2006; COCKWILL et al., 2007; OHAD et al., 2010; FENIMORE et al., 2011; SHELNUTT et al., 2017), in comparison to humans (BROUQUI \& RAOULT, 2006). Also, life expectancy is considerably shorter among dogs presenting the disease (MACDONALD et al., 2004; SYKES et al., 2006; CHOMEL et al., 2009). Bartonella spp. are arthropod-borne Gram-negative fastidious alpha-proteobacteria that show predisposition to infecting erythrocytes and endothelial cells. Their presence has also been associated with vascular proliferative lesions (CHOMEL et al., 2009).

Even though Bartonella-associated endocarditis has been reported in both humans and animals, including those that are considered to be reservoirs for this group of bacteria, the majority of Bartonella-associated endocarditis cases have been reported in dogs (CHOMEL et al., 2009). Based on molecular and/or isolation techniques, B. quintana (KELLY et al., 2006), B. clarridgeiae (MACDONALD et al., 2004; CHOMEL et al., 2001; 2009), B. rochalimae (HENN et al., 2009), B. vinsonii subsp. berkhoffi (BREITSCHWERDT et al., 1995, 1999; MACDONALD et al., 2004; COCKWILL et al., 2007; FENIMORE et al., 2011; SHELNUTT et al., 2017), B. henselae (OHAD et al., 2010; FENIMORE et al., 2011), B. washoensis (CHOMEL et al., 2003) and B. koeblerae (OHAD et al., 2010) have been reported as causal agents of endocarditis in dogs. To date, confirmed cases of endocarditis caused by Bartonella species have been reported in dogs in the USA, Canada, New Zealand (CHOMEL et al., 2009) and Israel (OHAD et al., 2010).

To add to this scenario, we present a clinical case of a canine patient in Brazil that was diagnosed with endocarditis caused by Bartonella clarridgeiae, with emphasis on the echocardiographic, clinicopathological and histopathological aspects of the disease.

\section{Materials and Methods}

\section{Tissue samples}

Fragments from the patient's vegetative aortic valve lesions and myocardium (tissue samples) and a blood clot that was adhering to the aortic valve (biological sample) were collected during necropsy. These samples were stored in RNAse and DNAse-free microtubes at $-70^{\circ} \mathrm{C}$ for subsequent DNA extraction and culturing.

\section{Culturing}

The tissue and biological samples were subjected to pre-enrichment liquid culturing using an insect-based medium, as previously described, but with modifications (MAGGI et al., 2005; DUNCAN et al., 2007; DRUMMOND et al., 2018). The fragments were macerated in $2 \mathrm{~mL}$ of Bartonella-alpha proteobacteria growth medium (BAPGM) and were kept under agitation at $37^{\circ} \mathrm{C}$ with $5 \% \mathrm{CO}_{2}$ for 10 days. Then, $200 \mu \mathrm{L}$ of each enrichment liquid culture were seeded onto a solid culturing medium of enriched chocolate agar (MAGGI et al., 2005; DUNCAN et al., 2007) and were maintained under the same conditions for up to six weeks. Colonies suggestive of these bacteria were individually collected, subjected to DNA extraction by boiling and submitted to a qPCR assay for Bartonella spp. based on nuoG gene. The remainder of each enrichment liquid culture was also subjected to DNA extraction and qPCR assay.

\section{Molecular analysis}

DNA was extracted from $25 \mathrm{mg}$ of each aortic valve lesion and myocardium fragments, and from $1 \mathrm{~mL}$ of BAPGM liquid culture on each type of material (i.e. aortic valve lesion, myocardium and blood clot), thus totaling five samples. For this purpose, the Illustra Tissue and Cell Genomic Prep Mini Spin kit (GE Healthcare, UK) was used, following the manufacturer's instructions. Nuclease-free water (Promega Corporation, Madison, USA) was also extracted with the same batch of tissue samples, in order to rule out the occurrence of cross-contamination of DNA extraction reagents in the lab. The DNA quality was evaluated based on the concentration and the 260/280 and 260/230 $\mathrm{nm}$ ratios, using a spectrophotometer (Nanodrop, Thermo Scientific, USA).

For the tissue fragments, a conventional PCR (cPCR) assay based on the endogenous mammalian gene glyceraldehyde-3-phosphate dehydrogenase (GAPDH) (BIRKENHEUER et al., 2003) was performed in order to evaluate the presence of amplifiable DNA.

A qPCR based on the nuoG gene was performed to detect and quantify the number of DNA copies/ $\mathrm{LL}$ of Bartonella spp. in each sample (ANDRÉ et al., 2015). According to André et al. (2015), this qPCR assay was designed based on 20 nuo $G$ sequences of phylogenetically distant Bartonella species. Serial dilutions were performed to construct standard curves with different concentrations $\left(2.0 \times 10^{7}\right.$ to $2.0 \times 10^{0}$ copies $)$ of the plasmid, which encodes a fragment of the 83 bp nuo $G$ gene for $B$. henselae DNA (pIDTSMART; Integrated DNA Technologies), diluted in Tris-EDTA (TE; 10 mmol/l, Tris-HCl, 0.1 mmol/l, EDTA) (pH 8.0).

Samples that were found to be positive in the above mentioned qPCR were subjected to CPCR assays based on five different genes, namely: $g l t A$ (pb)(BILLETER et al., 2011), $r p o B$ (PAZIEWSKA et al., 2011), ftsZ (MAGGI \& BREITSCHWERDT, 2005), pap-31 (MAGGI \& BREITSCHWERDT, 2005) and ribC (JOHNSON et al., 2003). Bartonella henselae that had been detected in a naturally infected cat (ANDRÉ et al., 2015) and Nuclease-Free Water (Promega Corporation, Madison, USA) were used as the positive and negative controls, respectively, in 
both quantitative real-time and conventional PCR assays for Bartonella spp.

The products obtained in all the cPCR assays were separated by means of electrophoresis on $1 \%$ agarose gels stained with ethidium bromide (Life Technologies ${ }^{\mathrm{TM}}$, Carlsbad, California, USA), at $100 \mathrm{~V}$ and $150 \mathrm{~mA}$ for $50 \mathrm{~min}$. The gels were then imaged under ultraviolet light (ChemiDoc MP Imaging System, Bio Rad'TM, Hercules, California, USA) using the Image Lab software, version 4.1 .

\section{Sequencing and phylogenetic analysis}

The amplified products were purified using the Silica Bead DNA Gel Extraction kit (Thermo Fisher Scientific, Waltham, MA, USA) and were sequenced using the BigDye Terminator v3.1 Cycle Sequencing kit (Thermo Fisher Scientific ${ }^{\text {TM }}$, Waltham, MA, USA) and the ABI PRISM 310 DNA Analyzer (Applied Biosystems $^{\mathrm{TM}}$, Foster City, CA, USA) (SANGER et al., 1977).

The sequences obtained were analyzed using the Phred-Phrap v.2.3 software (EWING \& GREEN, 1998) to evaluate the quality of the electropherogram and to obtain the consensus sequence from the alignment of the sense and antisense sequences (EWING et al., 1998). DNA sequence of the forward and reverse primers used in each one of the PCR assays were removed from the consensus sequence for each gene after chromatograms were reviewed and before phylogenetic trees were constructed. Each consensus sequence was compared with previous sequences deposited in GenBank (BENSON et al., 2017) by means of BLASTn (ALTSCHUL et al., 1990), and then aligned with other sequences retrieved from GenBank using the MAFFT software, version 7 (KATOH \& STANDLEY, 2013).

The phylogenetic analysis was based on the Bayesian inference method (BI), performed using MrBayes 3.1.2 (RONQUIST \& HUELSENBECK, 2003) via the CIPRES Science Gateway. Markov chain Monte Carlo (MCMC) simulations were run for $10^{6}$ generations with a sampling frequency of every 100 generations and a burn-in of $25 \%$. The best evolutionary model was chosen using the jModelTest2 software (version 2.1.6) on XSEDE (DARRIBA et al., 2012) via the CIPRES Science Gateway (MILLER et al., 2011).

\section{Results}

\section{Case report}

In April 2018, a 10-year-old mixed-breed male dog weighing $20 \mathrm{~kg}$ was admitted to the Small Animal Medicine Division of our institution's teaching hospital, presenting anorexia and progressive weight loss. The patient had been sharing its household (located in Jaboticabal, state of São Paulo, southeastern Brazil) with one cat. Both the patient and its cohort cat had access to the outdoors. Although no ectoparasites were observed in the physical inspection of the patient, the owner reported that ectoparasiticides had infrequently been used.

In the clinical examination, a cardiac murmur was noticed through auscultation. Therefore, the patient was then referred to the Veterinary Cardiology Division for more detailed evaluation. Dyspnea, hypophonesis of heart sounds and bilateral diffuse pulmonary crepitation were additionally observed. The patient received an intravenous bolus of furosemide $(2 \mathrm{mg} / \mathrm{kg})$ and pericardiocentesis was performed after the patient's condition had stabilized.

The clinical evaluation was reviewed after the patient had improved from the dyspnea. A grade V/VI systolic and diastolic murmur was detected, with mitral, tricuspid, pulmonary and aortic foci. The patient was also hyperthermic $\left(40{ }^{\circ} \mathrm{C}\right)$ and cachectic, with a body score of $2 / 9$. Cardiomegaly and presence of a diffuse alveolar pattern in the lung fields were observed during a thoracic radiographic evaluation.

Blood samples were obtained for hematological and biochemical analyses. The main detected abnormalities were normocytic and normochromic anemia (hematocrit: 26\%; mean corpuscular volume: $73.8 \mathrm{fL}$; mean corpuscular hemoglobin concentration: $33.9 \mathrm{~g} / \mathrm{dL})$; leukocytosis without a left shift $(23,300 / \mu \mathrm{L})$; increased Blood Urea Nitrogen (BUN) $(172 \mathrm{mg} / \mathrm{dL})$ and mild hyperproteinemia $(8.2 \mathrm{~g} / \mathrm{dL})$.

Left atrioventricular volume overload was diagnosed qualitatively through echocardiographic examination, shown by bulging of the interventricular septum and increased left ventricular diameter during diastole (LVDd: $59.7 \mathrm{~mm}$ ). Systolic dysfunction was also identified based on increased left ventricular diameter during systole (LVDs: $36.5 \mathrm{~mm}$ ). These measurements were made in the right parasternal window at the transverse axis in the chordal plane by means of M-mode. An increased left atrium (LA) to aorta (Ao) ratio $(\mathrm{LA} / \mathrm{Ao}=2.10)$ was shown by means of the two-dimensional mode in the aortic plane (transverse axis).

The patient also presented moderate pulmonary hypertension, which was estimated by means of the pressure gradient (P.G.) of tricuspid regurgitation, thus adding to the estimated pressure of the right atrium (P.G.: $51.7 \mathrm{mmHg}+10 \mathrm{mmHg}=61.7 \mathrm{mmHg}$ ). In addition, right atrioventricular volume overload was observed, based on qualitative evaluation of two-dimensional images (longitudinal plane, 4 and 5 chambers; and apical plane, 4 and 5 chambers).

Lastly, presence of irregular hyperechogenic structures adhering to the aortic leaflets was observed. These structures caused obstruction of the left ventricular outflow tract, and severe aortic insufficiency was identified (Figure 1). The structures had dimensions of approximately $10 \mathrm{~mm}$ x $4 \mathrm{~mm}$ and $12.2 \mathrm{~mm}$ x $8.6 \mathrm{~mm}$ (Figure 2). Aortic stenosis was confirmed, with a pressure gradient between the left ventricle and the aorta of nearly $80 \mathrm{mmHg}$ (Figure 3). The electrocardiogram showed a sinus rhythm, with heart rate of $120 \mathrm{bpm}$, increased $\mathrm{R}$ wave amplitude $(3.23 \mathrm{mV})$ and increased duration of the QRS complex (67 ms), suggestive of left ventricular overload.

Because the owner had limited financial resources, conventional blood culture was not performed. The therapeutic diagnosis of endocarditis was suggested based only on the clinical signs, laboratory abnormalities and echocardiogram. Thus, antimicrobial therapy was instituted, consisting of a combination of benzathine penicillin (q5 days, IM), metronidazole $(30 \mathrm{mg} / \mathrm{kg}, \mathrm{IV}, \mathrm{q} 24 \mathrm{~h}$ ) and enrofloxacin $(10 \mathrm{mg} / \mathrm{kg}, \mathrm{IV}, \mathrm{q} 24 \mathrm{~h})$. To treat congestive heart failure, furosemide (2 mg/kg, orally, q12h), enalapril maleate 

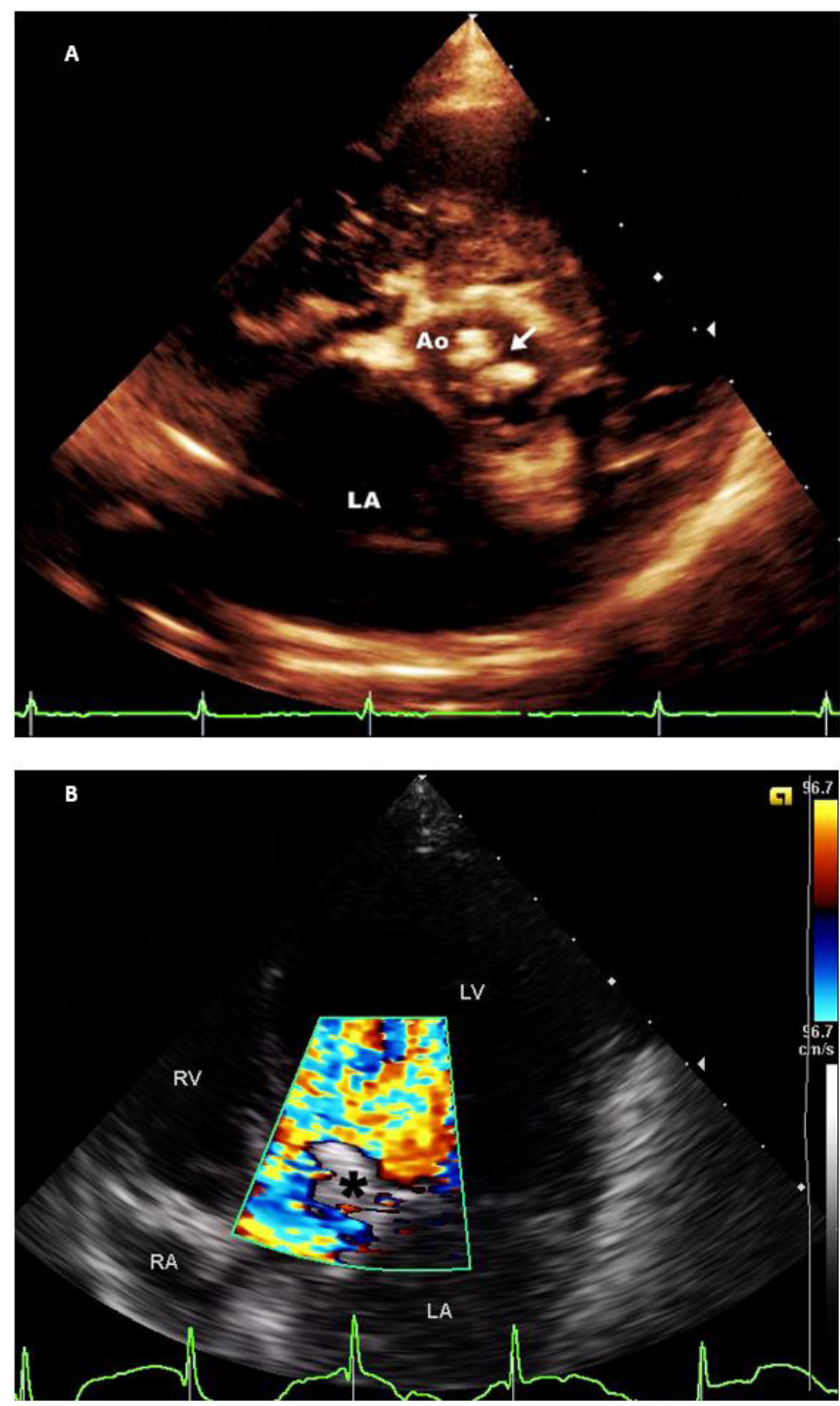

Figure 1. Echocardiographic image obtained from the left parasternal window - apical 5 chambers plane. (A) Presence of vegetative structure (arrow) adhered to aortic leaflets, causing obstruction of the left ventricular outflow tract; (B) Color Doppler is showing swirling blood flow in the left ventricular outflow tract bypassing the vegetative structure $\left(^{*}\right)$. Ao, aortic; LA, left atrium; LV, left ventricle; RA, right atrium; RV, right ventricle; left ventricle outflow tract.

( $0.45 \mathrm{mg} / \mathrm{kg}$, orally, q12h), spironolactone $(2 \mathrm{mg} / \mathrm{kg}$, orally, q24h) and sildenafil ( $1 \mathrm{mg} / \mathrm{kg}$, orally, q12h) were prescribed.

The patient was followed up for 21 days and, after that period, showed clinical signs of dehydration, azotemia, emesis, hyporexia, increased systolic blood pressure (ranging from 250 to $120 \mathrm{mmHg}$ after therapy) and pericardial effusion. During this period, palliative therapy was then instituted based on intravenous fluid therapy ( $4 \mathrm{ml} / \mathrm{kg} / \mathrm{h}$; lactated Ringer's solution supplemented with B complex), ondansetron ( $1 \mathrm{mg} / \mathrm{kg}$, orally, $\mathrm{q} 12 \mathrm{~h})$, ranitidine $(1 \mathrm{mg} / \mathrm{kg}$, orally, $\mathrm{q} 12 \mathrm{~h}$ ) and a balanced homemade diet. On the other hand, the treatment (especially the antimicrobial therapy) was not adequately implemented, due to lack of collaboration by the owner regarding the outpatient treatment. The dog's clinical signs deteriorated and
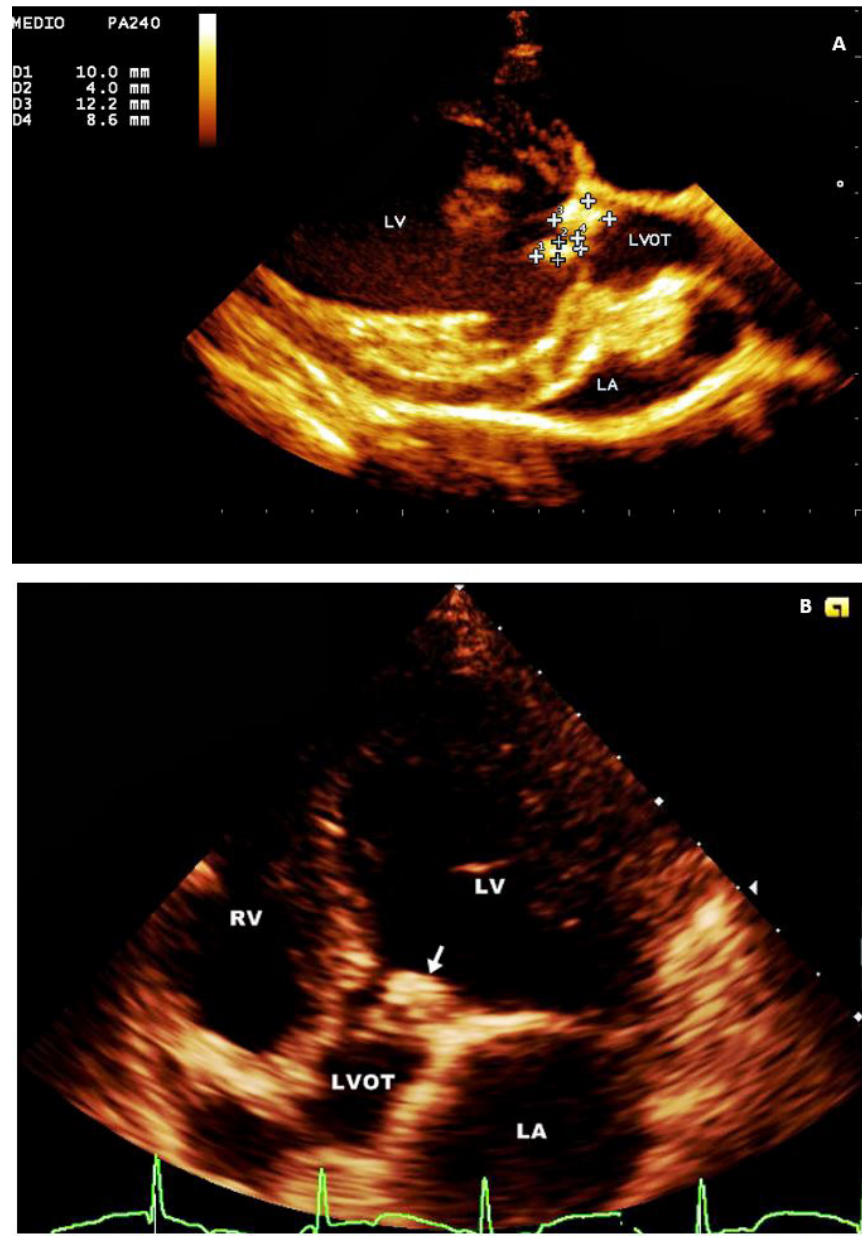

Figure 2. Echocardiographic image obtained from the right parasternal window. (A) Longitudinal 5 chambers plane with vegetative structures measured (+) in two aortic leaflets; (B) Transversal axis at the aortic plane with vegetative structures adhered to aortic leaflets (arrow). LA, left atrium; LV, left ventricle; LVOT, left ventricular outflow tract; RV, right ventricle.

the animal then died due to cardiopulmonary arrest. The patient's body was sent to the Veterinary Pathology Service for necropsy and analysis of structures adhering to the aortic valves.

At the Veterinary Pathology Service, a macroscopic analysis was conducted. This showed that the heart presented increased volume, with a focal whitish area in the apex region. On cutting the heart open, right ventricular dilatation and increased left ventricular wall thickness were observed. When the aortic artery was sectioned, a vegetative, whitish, hardened structure measuring $1.0 \mathrm{~cm}$ in diameter was observed in the aortic semilunar valve. Microscopic analysis showed the presence of fibrin mixed with cellular debris (leukocytes), areas of fibrosis and foci of dystrophic calcification in the lesion. In the atrial and ventricular myocardium, there were multifocal areas of fibrosis and fiber necrosis, a slight focus of inflammatory lymphocytic infiltrate and a focus of dystrophic calcification adjacent to the vessel of the cardiac interstitium. The microscopic diagnosis was chronic endocarditis associated with areas of multifocal fibrosis in the atrial and ventricular myocardium (Figure 4). 


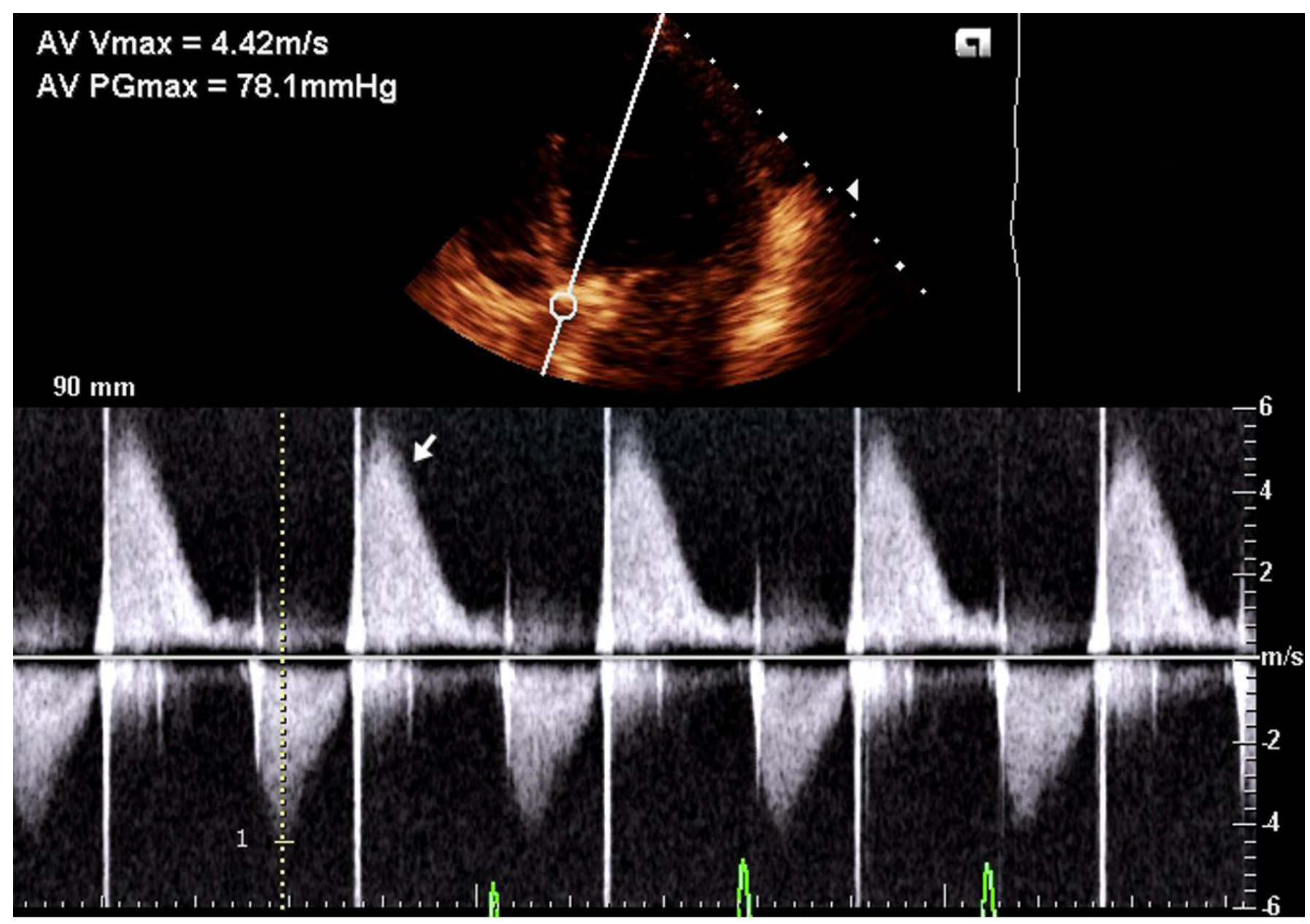

Figure 3. Echocardiographic image obtained from the left parasternal window - apical 5 chambers plane. Continuous Doppler spectrum shows aortic flow with increased velocity $(4.42 \mathrm{~m} / \mathrm{s})$ and aortic insufficiency (arrow).

\section{Molecular detection and characterization}

The DNA samples extracted from the aortic valve lesion and myocardium tissues were positive for the mammalian endogenous gapdh gene in the cPCR assay. The mean DNA concentration was $28.25 \mathrm{ng} / \mu \mathrm{L}$ and the $260 / 280 ; 260 / 230$ absorbance ratios were 2.32 and 1.10 , respectively.

The DNA sample obtained directly from the aortic valve lesion tissue was the only one that was positive for Bartonella spp. in qPCR based on the nuoG gene, with quantification of $5.68 \times 10^{3}$ copies $/ \mu \mathrm{L}$ of DNA. When subjected to pre-enrichment liquid culturing, an increase in quantification of Bartonella-nuo $G$ copies $/ \mu \mathrm{L}$ was observed $\left(1.41 \times 10^{5} \pm 1.00 \times 10^{4}\right.$ copies $\left./ \mu \mathrm{L}\right)$. The efficiency, $\mathrm{R}^{2}$, slope and Y-intercept of the reactions ranged from $103.8 \%$ to $104.3 \%, 0.997$ to $0.998,-3.223$ to -3.233 and 37.336 to 37.457 , respectively. Even though the myocardium tissue and blood clot samples were shown to be negative before the pre-enrichment liquid culturing, both samples showed positive results from qPCR after liquid culturing. The suggestive colonies that were obtained on the chocolate agar plates were shown to be negative in the qPCR assay for Bartonella spp. based on nuo G gene.
The DNA sample from the aortic valve lesion tissue was positive only for the glt $A$ gene, and showed negative results in the remaining cPCR assays ( $f t s Z, r p o B$, pap-31 and $r i b C$ genes). The sequence obtained was deposited in GenBank, with the accession number MK977726. In the analysis performed using BLASTn, the sequence found showed $100 \%$ similarity $(100 \%$ query coverage) with a Bartonella clarridgeiae sequence that had been detected in cat fleas (Ctenocephalides felis) in Chile (GenBank accession number KY913636). The phylogenetic tree inferred through Bayesian analysis allocated the sequence obtained in the present study in the clade of $B$. clarridgeiae detected in Chile, China and Tunisia, with 100\% clade support (Figure 5).

\section{Discussion}

The diagnosis of IE in dogs is usually based on clinical-pathological and echocardiographic features or pathological lesions (MACDONALD et al., 2004). The abnormalities found in the dog of the present report were similar to those previously reported from dogs with Bartonella-associated endocarditis, such as murmur, fever, anorexia, respiratory abnormalities, weakness and collapse 


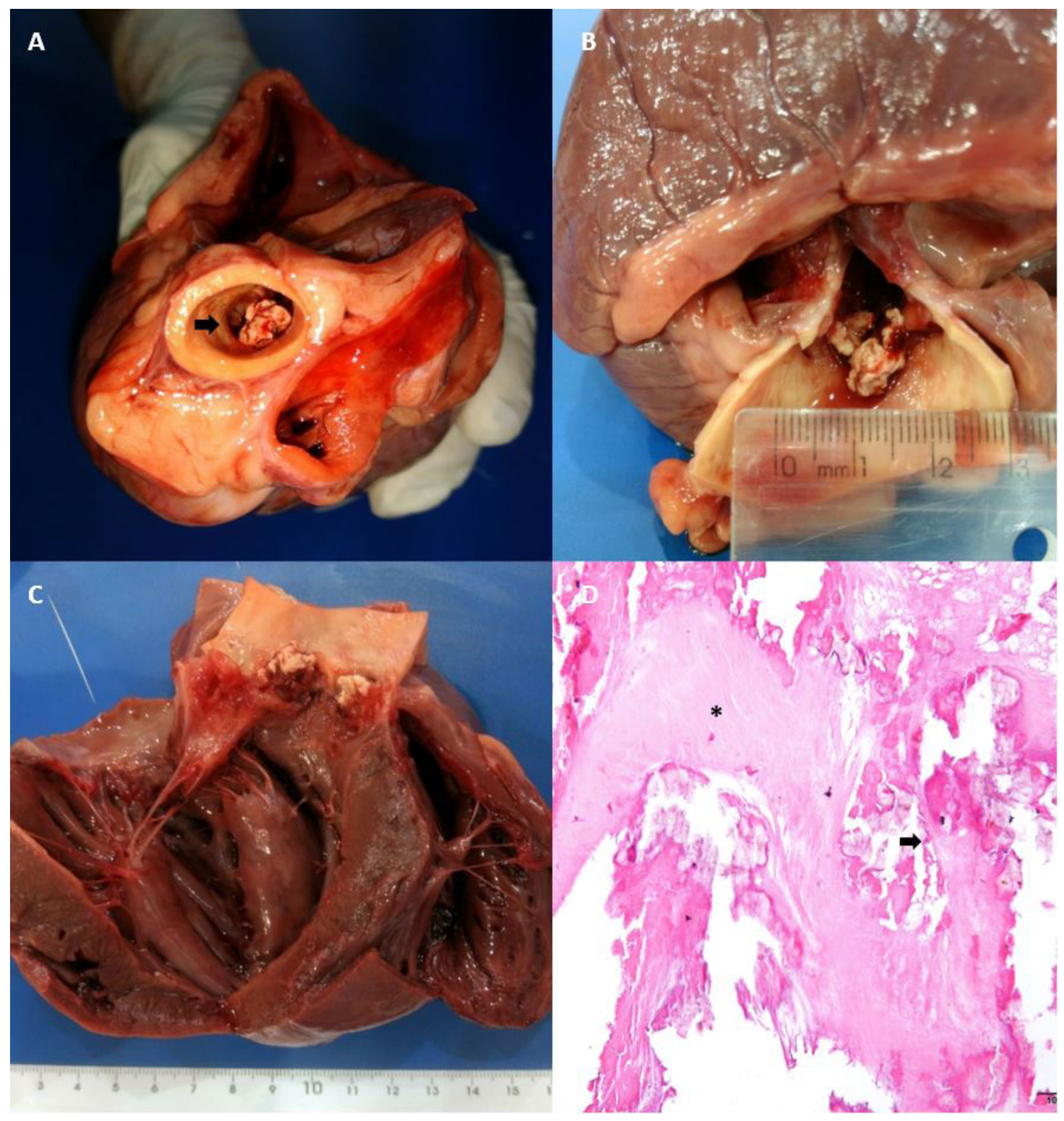

Figure 4. Anatomopathological features in dogs with endocarditis by Bartonella clarridgeiae. (A) A vegetative-like lesion observed in the lumen of the aorta (arrow); (B) Proliferation observed in the semilunar aortic valve in detail; (C) Hypertrophied left ventricle; (D) Microscopic aspect of the vegetative-like lesion, with fibrous tissue (asterisk) and calcification foci (arrow) (hematoxylin and eosin staining).

(CHOMEL et al., 2009). Even though lack of fever has been frequently reported among dogs presenting Bartonella-associated endocarditis, the patient of the present study showed hyperthermia. Considering that blood cultures for endocarditis-associated pathogens (such as E. coli, Streptococcus spp., Pseudomonas spp. or Corynebacterium spp.) (MACDONALD et al., 2004) were not performed neither at the time of attending our patient because of the owner's financial restraints nor during the necropsy procedures, we cannot rule out the possibility that co-infection with additional bacterial pathogens might have been present.

Like in previous reports, the prognosis for this dog's IE was grave. This prognosis became the reality through its death 30 days after its first admission to the hospital. Dogs presenting Bartonella-associated endocarditis often developed severe aortic 


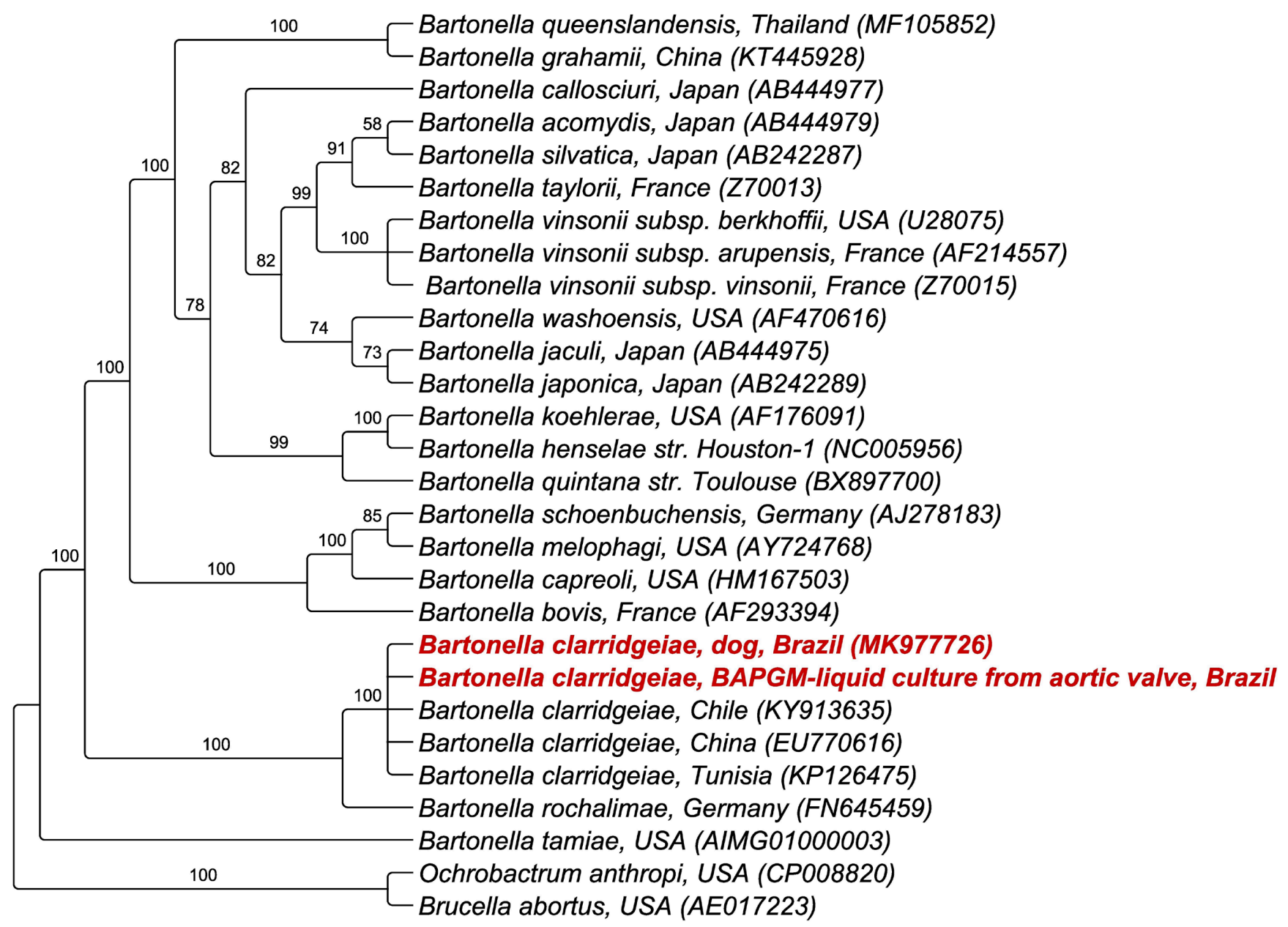

Figure 5. Phylogenetic analysis of Bartonella sequences based on the gltA gene and using the Bayesian Inference method with TIM3 evolution model with invariable sites and gamma distribution. The numbers on the nodes correspond to the posterior probability values. The sequence found in the present study is highlighted in red. Brucella abortus and Ochrobactrum anthropi were used as an external group.

insufficiency, thus resulting in rapid development of congestive heart failure and death (MACDONALD et al., 2004).

Here, the diagnosis of Bartonella clarridgeiae-associated endocarditis was supported by the qPCR assays based on the nuo $G$ gene and on additional phylogenetic inferences based on the glt $A$ gene, as previously suggested (GUTIÉRREZ et al., 2017; KOSOY et al., 2018). Analysis of large enough glt $A$ gene fragments has historically been used to compare Bartonella strains, since this provides good discriminatory power at the species level (KOSOY et al., 2018; GUTERRES et al., 2019).

Previously, B. clarridgeiae-associated endocarditis had been reported in three dogs in California, USA (MACDONALD et al., 2004; CHOMEL et al., 2001, 2009). Therefore, the present study showed the first confirmed case of $B$. clarridgeiae-associated endocarditis in a dog outside the USA. In Brazil, although infection by Bartonella species, including $B$. clarridgeiae, has been extensively reported (BRAGA et al., 2012; MICELI et al., 2013; ANDRÉ et al., 2014, 2015), few studies have focused on the seroprevalence and molecular detection of bartonellae in dogs. In a previous study, antibodies to $B$. henselae and $B$. vinsonii subsp. berkhoffi $i$ were detected in 2.0\% (4/197) and 1.5\% (3/197) of dogs showing clinical pathological abnormalities suggestive of tick-borne diseases, respectively. Bartonella henselae and B. vinsonii subsp. berkhoffi co-infection was found in one of the B. vinsonii subsp. berkhoffi seroreactive dogs (DINIZ et al., 2007). Interestingly, antibodies to Bartonella spp. were detected in 11 (11.3\%) out of 97 Neotropical wild canids that were being kept in captivity in Brazilian zoos. Among the seropositive wild canids, the majority was found to be seropositive for B. clarridgeiae (FLEISCHMAN et al., 2015). Based on BAPGM enrichment blood culturing, PCR and DNA sequencing platform, B. clarridgeiae was detected in an asymptomatic blood donor in southeastern Brazil (VIEIRA-DAMIANI et al., 2015).

The source of infection and transmission route of $B$. clarridgeiae for this dog remains unknown. Considering that the dog had outdoor access and shared its environment with cats, and that ectoparasiticides were not routinely used on the household animals, we would suggest that $B$. clarridgeiae infection was achieved through fleas from infected cats, which are considered to be the main reservoirs for $B$. clarridgeiae (KORDICK \& BREITSCHWERDT, 1998). Ctenocephalides felis felis is the vector incriminated for 
transmission of $B$. clarridgeiae among cats (BREITSCHWERDT $\&$ KORDICK, 2000). It is also the flea most frequently found parasitizing dogs (RUST, 2017).

The main hematological and biochemical abnormalities found in the present study were normocytic normochromic anemia, leukocytosis without left shift, proteinuria, hyperproteinemia, gammaglobulinemia and azotemia. These findings had previously been reported in dogs with endocarditis secondary to Bartonella spp. infection (BREITSCHWERDT et al., 1999; MACDONALD et al., 2004; KELLY et al., 2006; COCKWILL et al., 2007; CHOMEL et al., 2009; FENIMORE et al., 2011; SHELNUTT et al., 2017).

Cardiomegaly and cardiogenic pulmonary edema in the lungs were observed in the thoracic radiographic evaluation of the present study. This finding corroborated previous reports on Bartonella-associated endocarditis in dogs (MACDONALD et al., 2004; COCKWILL et al., 2007; CHOMEL et al., 2003). The electrocardiogram showed increased $\mathrm{R}$ wave amplitude and QRS complex duration, suggestive of left ventricular overload, as also previously reported (CHOMEL et al., 2001). Echocardiography confirmed the presence of a large vegetative lesion on the aortic valve that caused stenosis and severe aortic insufficiency, with left and right atrioventricular volume overload, as shown in previous reports (CHOMEL et al., 2001; KELLY et al., 2006; COCKWILL et al., 2007; HENN et al., 2009).

In the present study, the main macroscopic and histological alterations observed were vegetative valvular endocarditis, fibrosis and dystrophic mineralization. Endocarditis secondary to Bartonella infection in dogs has been associated with combinations of fibrosis, mineralization, endothelial proliferation and neovascularization, with variable inflammation. Even though none of these features can be considered specific for Bartonella infection, combinations of these findings make it possible to distinguish this condition from both endocarditis caused by culturable bacteria and endocardiosis (PESAVENTO et al., 2005).

The present work supports previous studies on humans (RAOULT et al., 1996, 2003) and dogs that showed that Bartonella species preferentially infect the aortic valve (BREITSCHWERDT et al., 1995, 1999; CHOMEL et al., 2001; MACDONALD et al., 2004; KELLY et al., 2006; COCKWILL et al., 2007; HENN et al., 2009; FENIMORE et al., 2011; SHELNUTT et al., 2017) and, less often, the mitral valve concomitantly or alone (BREITSCHWERDT et al., 1999; MACDONALD et al., 2004; KELLY et al., 2006; COCKWILL et al., 2007; FENIMORE et al., 2011; SHELNUTT et al., 2017). It is most likely that endocarditis is a consequence of chronic Bartonella infection with occasional presence of bacteria in the heart valve (BREITSCHWERDT et al., 1999). Myocarditis, which has also been associated with Bartonella infection in dogs, with or without an association with valve endocarditis (BREITSCHWERDT et al., 1999; FENIMORE et al., 2011; SHELNUTT et al., 2017), was not observed in the dog of the present study.

Ideally, the diagnostic work-up to investigate IE in dogs should include serological tests for Bartonella (MACDONALD et al., 2004) and/or culturing in BAPGM followed by PCR (DUNCAN et al., 2007). Considering that serological tests for Bartonella species affecting dogs were not available at the time of sampling, the diagnosis in the present case relied on molecular detection from both aortic valve lesion and BAPGM liquid culture. Even though this latter technique gave rise to a greater number of Bartonella $n u o G$ copies per microliter in BAPGM liquid culture than what was achieved in DNA extracted directly from the aortic valve lesion, isolation on chocolate agar plates was not successful. The failure in isolating Bartonella in the present study could be related to the conditions in which culturing was performed. Duncan et al. (2007) optimized the protocol for $B A P G M$ pre-enrichment medium previously established (MAGGI et al., 2005) by increasing the final volume of defibrinated sheep blood (from 5\% to 10\%), and by reducing both the $\mathrm{pH}$ (from 7.4 to 6.2) and period of incubation (from 10 to 7 days), followed by a sub-inoculation onto blood agar at $35^{\circ} \mathrm{C}$ and $5 \% \mathrm{CO}_{2}$ for up to 3 weeks. While in the present study we used chocolate agar under $37^{\circ} \mathrm{C}$ and $5 \% \mathrm{CO}_{2}$ atmosphere for culturing, Chomel et al. $(2001,2003)$ successfully isolated $B$. clarridgeiae and $B$. washoensis from dogs with aortic and mitral valve endocarditis, respectively, by culturing dogs' blood samples on heart infusion agar containing 5\% rabbit blood and incubated at $5 \% \mathrm{CO}_{2}$ in a $35^{\circ} \mathrm{C}$ atmosphere for up to 4 weeks. Recently, $B$. henselae was isolated from cats blood samples in southeastern Brazil using a platform combining BAPGM liquid culture for 10 days followed by inoculation on agar containing $30 \%$ sheep blood, under incubation at $5 \% \mathrm{CO}_{2}$ and $37^{\circ} \mathrm{C}$ for 45 days (DRUMMOND et al., 2018). Nonetheless, the absence of colonies in solid medium has already been reported for blood samples from dogs showing positive results in qPCR assays based on BAPGM liquid cultures (DUNCAN et al., 2007).

Given that dogs play a role as excellent sentinels for Bartonella infections, since they can become infected with the same Bartonella species as those that cause endocarditis in humans (CHOMEL et al., 2006), future surveillance studies should be conducted in order to evaluate how widespread Bartonella infection is among pet and stray dogs in Brazil.

The present work highlights the importance of awareness of emerging vector-borne infectious diseases, even in regions presumed to be non-endemic. Here, $B$. clarridgeiae was identified as the cause of endocarditis in a dog for the first time in Latin America. It would be preferable to make the diagnosis of Bartonella spp. bacteremia before clinical signs or hematological disorders are manifested. This could be achieved by means of a diagnostic platform combining serological techniques and an insect-based enrichment liquid-medium culturing approach, followed by highly sensitive PCR assays. Application of standardized procedures of this nature would make it possible to introduce effective antibiotics at an early stage of disease progression, with the aim of diminishing the morbidity and mortality associated with Bartonella-induced endocarditis and/or myocarditis, as previously recommended (SHELNUTT et al., 2017).

\section{Acknowledgements}

The authors would like to thank the "Fundação de Amparo à Pesquisa do Estado de São Paulo” (Process number \#2018/02753-0) for the financial support. MRA is a fellowship researcher of "Conselho Nacional de Desenvolvimento Científico e Tecnológico" (CNPq Process number \#302420/2017-7). 


\section{References}

Altschul SF, Gish W, Miller W, Myers EW, Lipman DJ. Basic local alignment search tool. J Mol Biol 1990; 215(3): 403-410. http://dx.doi. org/10.1016/S0022-2836(05)80360-2. PMid:2231712.

André MR, Baccarim Denardi NC, Sousa KCM, Gonçalves LR, Henrique PC, Ontivero CRGR, et al. Arthropod-borne pathogens circulating in free-roaming domestic cats in a zoo environment in Brazil. Ticks Tick Borne Dis 2014; 5(5): 545-551. http://dx.doi.org/10.1016/j.ttbdis.2014.03.011. PMid:24889035.

André MR, Dumler JS, Herrera HM, Gonçalves LR, de Sousa KC, Scorpio DG, et al. Assessment of a quantitative 5 ' nuclease real-time polymerase chain reaction using the nicotinamide adenine dinucleotide dehydrogenase gamma subunit (nuoG) for Bartonella species in domiciled and stray cats in Brazil. J Feline Med Surg 2015; 18(10): 783-790. http:// dx.doi.org/10.1177/1098612X15593787. PMid:26138812.

Benson DA, Cavanaugh M, Clark K, Karsch-Mizrachi I, Lipman DJ, Ostell J, et al. GenBank. Nucleic Acids Res 2017; 45(D1): D41-D47. http://dx.doi.org/10.1093/nar/gkw1070. PMid:27899564.

Billeter SA, Gundi VA, Rood MP, Kosoy MY. Molecular detection and identification of Bartonella species in Xenopsylla cheopis fleas (Siphonaptera: Pulicidae) collected from Rattus norvegicus rats in Los Angeles, California. Appl Environ Microbiol 2011; 77(21): 7850-7852. http://dx.doi. org/10.1128/AEM.06012-11. PMid:21908631.

Birkenheuer AJ, Levy MG, Breitschwerdt EB. Development and evaluation of a seminested PCR for detection and differentiation of Babesia gibsoni (Asian genotype) and B. canis DNA in canine blood samples. J Clin Microbiol 2003; 41(9): 4172-4177. http://dx.doi.org/10.1128/ JCM.41.9.4172-4177.2003. PMid:12958243.

Braga MS, Diniz PP, André MR, Bortoli CP, Machado RZ. Molecular characterisation of Bartonella species in cats from São Luís, state of Maranhão, north-eastern Brazil. Mem Inst Oswaldo Cruz 2012; 107(6): 772-777. http://dx.doi.org/10.1590/S0074-02762012000600011. PMid:22990968.

Breitschwerdt EB, Atkins CE, Brown TT, Kordick DL, Snyder OS. Bartonella vinsonii subsp. berkhoffi and related members of the alpha subdivision of the proteobacteria in dogs with cardiac arrhythmias, endocarditis, or myocarditis. J Clin Microbiol 1999; 37(11): 3618-3626. PMid:10523564.

Breitschwerdt EB, Kordick DL, Malarkey DE, Keene B, Hadfield TL, Wilson K. Endocarditis in a dog due to infection with a novel Bartonella subspecies. J Clin Microbiol 1995; 33(1): 154-160. PMid:7699033.

Breitschwerdt EB, Kordick DL. Bartonella infection in animals: carriership, reservoir potential, pathogenicity, and zoonotic potential for human infection. Clin Microbiol Rev 2000; 13(3): 428-438. http://dx.doi. org/10.1128/CMR.13.3.428. PMid:10885985.

Brouqui P, Raoult D. New insight into the diagnosis of fastidious bacterial endocarditis. FEMS Immunol Med Microbiol 2006; 47(1): 1-13. http:// dx.doi.org/10.1111/j.1574-695X.2006.00054.x. PMid:16706783.

Chomel BB, Boulouis HJ, Maruyama S, Breitschwerdt EB. Bartonella spp. in pets and effect on human health. Emerg Infect Dis 2006; 12(3): 389-394. http://dx.doi.org/10.3201/eid1203.050931. PMid:16704774.

Chomel BB, Kasten RW, Sykes JE, Boulouis HJ, Breitschwerdt EB. Clinical impact of persistent Bartonella bacteremia in humans and animals. Ann N Y Acad Sci 2003; 990(1): 267-278. http://dx.doi. org/10.1111/j.1749-6632.2003.tb07376.x. PMid:12860639.
Chomel BB, Kasten RW, Williams C, Wey AC, Henn JB, Maggi R, et al. Bartonella endocarditis: a pathology shared by animal reservoirs and patients. Ann N Y Acad Sci 2009; 1166(1): 120-126. http://dx.doi. org/10.1111/j.1749-6632.2009.04523.x. PMid:19538271.

Chomel BB, MacDonald KA, Kasten RW, Chang CC, Wey AC, Foley $\mathrm{JE}$, et al. Aortic valve endocarditis in a dog due to Bartonella clarridgeiae. J Clin Microbiol 2001; 39(10): 3548-3554. http://dx.doi.org/10.1128/ JCM.39.10.3548-3554.2001. PMid:11574571.

Cockwill KR, Taylor SM, Philibert HM, Breitschwerdt EB, Maggi RG. Bartonella vinsonii subsp. berkhoffi i ndocarditis in a dog from Saskatchewan. Can Vet J 2007; 48(8): 839-844. PMid:17824328.

Darriba D, Taboada GL, Doallo R, Posada D. jModelTest 2: more models, new heuristics and parallel computing. Nat Methods 2012; 9(8): 772. http://dx.doi.org/10.1038/nmeth.2109. PMid:22847109.

Diniz PP, Maggi RG, Schwartz DS, Cadenas MB, Bradley JM, Hegarty $\mathrm{B}$, et al. Canine bartonellosis: serological and molecular prevalence in Brazil and evidence of co-infection with Bartonella henselae and Bartonella vinsonii subsp. berkhoffi. Vet Res 2007; 38(5): 607-710. http://dx.doi. org/10.1051/vetres:2007023. PMid:17583666.

Drummond MR, Lania BG, Diniz PPVP, Gilioli R, Demolin DMR, Scorpio DG, et al. Improvement of Bartonella henselae DNA detection in cat blood samples by combining molecular and culture methods. $J$ Clin Microbiol 2018; 56(5): e01732-e17. http://dx.doi.org/10.1128/ JCM.01732-17. PMid:29540455.

Duncan AW, Maggi RG, Breitschwerdt EB. A combined approach for the enhanced detection and isolation of Bartonella species in dog blood samples: pre-enrichment liquid culture followed by PCR and subculture onto agar plates. J Microbiol Methods 2007; 69(2): 273-281. http://dx.doi. org/10.1016/j.mimet.2007.01.010. PMid:17346836.

Ewing B, Hillier L, Wendl M, Green P. Base-calling of automated sequencer traces using phred. I. Accuracy assessment. Genome Res 1998; 8(3): 175-185. http://dx.doi.org/10.1101/gr.8.3.175. PMid:9521921.

Ewing GB, Green P. Base-calling of automated sequencer traces using phred. II. Error probabilities. Genome Res 1998; 8(3): 186-194. http:// dx.doi.org/10.1101/gr.8.3.186. PMid:9521922.

Fenimore A, Varanat M, Maggi R, Schultheiss P, Breitschwerdt EB, Lappin MR. Bartonella spp. DNA in cardiac tissues from dogs in Colorado and Wyoming. J Vet Intern Med 2011; 25(3): 613-616. http://dx.doi. org/10.1111/j.1939-1676.2011.0722.x. PMid:21539606.

Fleischman DA, Chomel BB, Kasten RW, André MR, Gonçalves LR, Machado RZ. Bartonella clarridgeiae and Bartonella vinsonii subsp. berkhoffii exposure in captive wild canids in Brazil. Epidemiol Infect 2015; 143(3): 573-577. http://dx.doi.org/10.1017/S0950268814001277. PMid:24892580.

Guterres A, Gonçalves J, Lemos ERS. What is the minimum length of gltA gene required for phylogenetic analyzes in Bartonella? Res Microbiol 2019; 170(1): 60-64. http://dx.doi.org/10.1016/j.resmic.2018.08.007. PMid:30217718.

Gutiérrez R, Vayssier-Taussat M, Buffet JP, Harrus S. Guidelines for the isolation molecular detection, and characterization of Bartonella species. Vector Borne Zoonotic Dis 2017; 17(1): 42-50. http://dx.doi.org/10.1089/ vbz.2016.1956. PMid:28055575.

Henn JB, Gabriel MW, Kasten RW, Brown RN, Koehler JE, MacDonald $\mathrm{KA}$, et al. Infective endocarditis in a dog and the phylogenetic relationship of the associated "Bartonella rochalimae" strain with isolates from dogs, 
gray foxes, and a human. J Clin Microbiol 2009; 47(3): 787-790. http:// dx.doi.org/10.1128/JCM.01351-08. PMid:19109472.

Johnson G, Ayers M, McClure SC, Richardson SE, Tellier R. Detection and identification of Bartonella species pathogenic for humans by PCR amplification targeting the riboflavin synthase gene (ribC). JClin Microbiol 2003; 41(3): 1069-1072. http://dx.doi.org/10.1128/JCM.41.3.10691072.2003. PMid:12624031.

Katoh K, Standley DM. MAFFT multiple sequence alignment software version 7: improvements in performance and usability. Mol Biol Evol 2013; 30(4): 772-780. http://dx.doi.org/10.1093/molbev/mst010. PMid:23329690.

Kelly P, Rolain JM, Maggi R, Sontakke S, Keene B, Hunter S, et al. Bartonella quintana endocarditis in dogs. Emerg Infect Dis 2006; 12(12): 1869-1872. http://dx.doi.org/10.3201/eid1212.060724. PMid:17326937.

Kordick DL, Breitschwerdt EB. Persistent infection of pets within a household with three Bartonella species. Emerg Infect Dis 1998; 4(2): 325-328. http://dx.doi.org/10.3201/eid0402.980225. PMid:9621208.

Kosoy M, McKee C, Albayrak L, Fofanov Y. Genotyping of Bartonella bacteria and their animal hosts: current status and perspectives. Parasitology 2018; 145(5): 543-562. http://dx.doi.org/10.1017/S0031182017001263. PMid:28764816.

MacDonald KA, Chomel BB, Kittleson MD, Kasten RW, Thomas WP, Pesavento P. A prospective study of canine infective endocarditis in northern California (1999-2001): emergence of Bartonella as a prevalent etiologic agent. J Vet Intern Med 2004; 18(1): 56-64. PMid:14765733.

Maggi RG, Breitschwerdt EB. Potential limitations of the 16S-23S rRNA intergenic region for molecular detection of Bartonella species. J Clin Microbiol 2005; 43(3): 1171-1176. http://dx.doi.org/10.1128/ JCM.43.3.1171-1176.2005. PMid:15750079.

Maggi RG, Duncan AW, Breitschwerdt EB. Novel chemically modified liquid medium that will support the growth of seven Bartonella species. J Clin Microbiol 2005; 43(6): 2651-2655. http://dx.doi.org/10.1128/ JCM.43.6.2651-2655.2005. PMid:15956379.

Miceli NG, Gavioli FA, Gonçalves LR, André MR, Sousa VR, Sousa $\mathrm{KC}$, et al. Molecular detection of feline arthropod-borne pathogens in cats in Cuiabá, state of Mato Grosso, central-western region of Brazil. Rev Bras Parasitol Vet 2013; 22(3): 385-390. http://dx.doi.org/10.1590/ S1984-29612013000300011. PMid:24142170.

Miller MA, Pfeiffer W, Schwartz T. The CIPRES science gateway: a community resource for phylogenetic analyses [online]. New Orleans: CIPRES; 2011 [cited 2019 Sep 24]. Available from: https://www.phylo.org
Ohad DG, Morick D, Avidor B, Harrus S. Molecular detection of Bartonella henselae and Bartonella koehlerae from aortic valves of Boxer dogs with infective endocarditis. Vet Microbiol 2010; 141(1-2): 182-185. http://dx.doi.org/10.1016/j.vetmic.2009.08.005. PMid:19716241.

Paziewska A, Harris PD, Zwolińska L, Bajer A, Siński E. Recombination within and between species of the alpha proteobacterium Bartonella infecting rodents. Microb Ecol 2011; 61(1): 134-145. http://dx.doi. org/10.1007/s00248-010-9735-1. PMid:20740281.

Pesavento PA, Chomel BB, Kasten RW, McDonald KA, Mohr FC. Pathology of Bartonella endocarditis in six dogs. Vet Pathol 2005; 42(3) 370-373. http://dx.doi.org/10.1354/vp.42-3-370. PMid:15872387.

Raoult D, Fournier PE, Drancourt M, Marrie TJ, Etienne J, Cosserat J, et al. Diagnosis of 22 new cases of Bartonella endocarditis. Ann Intern Med 1996; 125(8): 646-652. http://dx.doi.org/10.7326/0003-4819125-8-199610150-00004. PMid:8849149.

Raoult D, Fournier PE, Vandenesch F, Mainardi JL, Eykyn SJ, Nash J, et al. and the PMID. Outcome and treatment of Bartonella endocarditis. Arch Intern Med 2003; 163(2): 226-230. http://dx.doi.org/10.1001/ archinte.163.2.226. PMid:12546614.

Ronquist F, Huelsenbeck JP. MrBayes 3: bayesian phylogenetic inference under mixed models. Bioinformatics 2003; 19(12): 1572-1574. http:// dx.doi.org/10.1093/bioinformatics/btg180. PMid:12912839.

Rust MIK. The biology and ecology of cat fleas and advancements in their pest management: a review. Insects 2017; 8(4): 118. http://dx.doi. org/10.3390/insects8040118. PMid:29077073.

Sanger F, Nicklen S, Coulson AR. DNA sequencing with chain terminating inhibitors. Proc Natl Acad Sci USA 1977; 74(12): 5463-5467. http:// dx.doi.org/10.1073/pnas.74.12.5463. PMid:271968.

Shelnutt LM, Balakrishnan N, DeVanna J, Batey KL, Breitschwerdt EB. Death of military working dogs due to Bartonella vinsonii subspecies berkhoffi genotype III endocarditis and myocarditis. Mil Med 2017; 182(34): e1864-e1869. http://dx.doi.org/10.7205/MILMED-D-16-00125. PMid:28290975.

Sykes JE, Kittleson MD, Pesavento PA, Byrne BA, MacDonald KA, Chomel BB. Evaluation of the relationship between causative organisms and clinical characteristics of infective endocarditis in dogs: 71 cases (1992-2005). J Am Vet Med Assoc 2006; 228(11): 1723-1734. http:// dx.doi.org/10.2460/javma.228.11.1723. PMid:16740074.

Vieira-Damiani G, Diniz PP, Pitassi LH, Sowy S, Scorpio DG, Lania BG, et al. Bartonella clarridgeiae bacteremia detected in an asymptomatic blood donors. J Clin Microbiol 2015; 53(1): 352-356. http://dx.doi. org/10.1128/JCM.00934-14. PMid:25392353. 